\section{Global Trends in Funding Higher Education}

\section{JANDHYALA B. G. TILAK}

Jandhyala B. G. Tilak is professor at the National Institute of Educational Planning and Administration, New Delhi, India.Email: jtilak@vsnl.com.

$\mathrm{T}$ The decline in public expenditure on higher education has been a global crisis and the most important trend. Compelled by economic reform policies or convinced of the rationale for the reduced role of the state in funding higher education, most countries have inflicted serious cuts in public budgets for higher education. This trend exists in many countries, in some or all of the following areas: total public expenditure on higher education, per student expenditures, public higher education expenditure's share in relation to a particular country's national income or total government budget expenditure, and allocations in absolute and relative terms to important programs that include research, scholarships, and so on. The decline is not confined to developing countries, though it is more prevalent in developing than in developed countries. There has been a significant fall even in advanced countries such as the United Kingdom, Australia, and New Zealandthough generally higher education in high-income countries has not suffered much. The decline is steep in some countries-such as Botswana, Jamaica, Hungary, and New Zealand.

\section{INCREASE IN COST RECOVERY}

The decline in public expenditure is accompanied by increased efforts regarding cost recovery by introducing tuition fees in countries where higher education used to be provided free of charge and increasing fee rates in others where fees already existed. Though a good number of countries used to provide higher education for free, now except for a few countries (e.g., Brazil, Sri Lanka, Tanzania, and some European countries) a majority of countries now charge fees in higher education, in some cases small nominal and in others reasonably large amounts. Tuition fees were introduced in China and Britain in I998 and in Austria in 200I. In just a few countries-such as Sweden and Finland-tuition fees are not allowed in higher education by the national constitution. Some countries (e.g., India) have also hiked tuition fees selectively to equal the costs, while providing free or subsidized higher education to some or many students. This dual-track system of tuition fees is becoming common now in many countries.

While for social and political reasons, tuition fees have been neither introduced nor increased to very high levels in some countries, in several countries "user" charges are introduced or hiked for many services that universities used to provide free or at heavily subsidized prices-such as housing and food service in the university hostels, medical services, transport, in addition to price hikes for admissions application forms and the like. While tuition fees alone may not form a significant part of the universities' income, other student fees seem to account for ever higher proportions.

\section{Student loans: Solution or Problem}

Student-loan programs are becoming popular in many countries. However, loans as a mechanism for financing education are also associated with certain inherent weaknesses, apart from poor rates of recovery. In recent years, loans were introduced in many countries, such as China and Thailand, where they did not exist earlier. Loan programs were revitalized in many other countries, with a view to increasing the rates of recovery of loan amounts. Several loan programs were changed into income-contingent loans, and government-operated loan schemes were replaced by commercial bank-operated loan schemes (e.g., in India). While there seem to be shortterm financial benefits in the loan programs operated by commercial banks, in the long run the programs can create more problems than they solve. The fundamental assumption underlying loan programs is that higher education is neither a public good nor a social-merit good but, rather, a highly individualized private good, as the mechanism of loans shifts the

\section{While there seem to be short-term financial
benefits in the loan programs operated by com-
mercial banks, in the long run the programs
can create more problems than they solve.}

responsibility of funding higher education from society to families and more importantly within families from the parents to the individual students themselves.

\section{InCREASE in Nongovern mental Resources}

An equally important recent trend is governments' encouragement or insistence that public universities generate resources from "third parties" such as the corporate sector. Accordingly, public universities in many countries have created ways of generating funds from the corporate sector by selling services, mainly consultancy and physical products and patents. The corporate sector also finds it convenient to provide research funds to universities and research institutions, if such projects benefit businesses. An increasing reliance on corporate funds by universities may shift the balance of higher education's mission toward activities with the greatest commercial potential, in the end changing the very character of higher education institutions. Traditional academic disciplines of study and research may give way to market-relevant, resource-generating studies. Reliance on corporate funds may also lead to distortions in research priorities and even research outcomes. 


\section{The Mantra of Privatization}

Privatization has become the mantra of the day everywhere, including the case of higher education. In addition to the above-mentioned methods of financial privatization, governments in many countries seem increasingly to be getting wedded to the neoliberal philosophy that centers on the role of markets in every sphere. Governments promote the growth of private higher education institutions - most of which can be described as "for-profit" institutions. The wave of privatization of higher education has become so massive that even predominantly public higher education systems began to emerge as predominantly private in a very short period, making the relative presence of the public higher education sector almost invisible.

\section{The Purpose of Internationalization}

Lastly, in many countries the cuts in public funding also forced higher education institutions to look abroad for financing. Under the policy of internationalization, many universities have been following aggressive strategies to attract foreign students, who are charged fees above the per student costs. Foreign students thus subsidize the higher education of local students. It is unfortunate that even some of the best universities in the world, such as Oxford and Cambridge, also seem to be adopting the same approaches-contrary to what they did earlier, namely offering scholarships to foreign students to attract and promote the best talent. In the framework of the World Trade Organization, many countries find it convenient to sell cheap higher education degrees to gullible students in developing countries by adopting different modes under the General Agreement on Trade in Services. Universities are fast becoming entrepreneurial institutions both domestically and internationally.

\section{CONCLUSION}

The I998 UNESCO World Conference on Higher Education, the 2002 Report of the international Task Force on Higher Education and Society sponsored by the World Bank and UNESCO, and the 2004 World Bank policy paper on higher education, which all underscored the importance of public higher education in national development, have not made a significant impact on the policies of governments or international development organizations in relation to funding higher education. What seems to be forgotten is the golden rule in education: the best method of financing education, including higher education, is financing by the state through its tax and nontax revenues.

This is a shortened version of an article that appeared in IAU Horizons (March 2005) of the International Association of Universities.

\section{Student Loans in Thailand: From Social Targeting to Cost Sharing}

\section{ADRIAN Ziderman}

Adrian Ziderman is professor of economics at Bar-llan University, Israel, where he holds the Sir Isaac Wolfson Chair in Economics and Business Administration. Address: Economics Department, Bar-llan University, Ramat Gan 52900, Israel. E-mail: zidera@mail.biu.ac.il.

$\mathrm{T}$ he purpose served by government-sponsored student loan schemes varies from country to country. Two major but contrasting objectives for loan schemes may be identified.

Cost sharing: public universities throughout the world, and particularly in developing countries, are underfinanced; budgetary parsimony has resulted in public universities turning to greater cost recovery, in an effort to tap alternative sources of funding. This may take the form of higher, more realistic tuition fees or increased payments for subsidized lodgings and meals. Recourse to the banking system for a regular loan to ease this payment burden may be unavailable to students; banks are notoriously loath to lend for educational programsa clear case of market failure. Hence, there is a role for a government-backed student loan scheme to fill this gap.

Social targeting: these schemes are concerned explicitly and directly with enhancing the access to higher education of the poor. Where targeted specifically at disadvantaged groups, loan schemes (particularly where subsidized) can lead to greater access of the poor to university education, thus contributing to social equity.

\section{Social Targeting in the Thailand Scheme}

The student loan scheme in Thailand is a leading example of the social targeting model. The scheme, which began operations in 1996, is aimed specifically at disadvantaged students, enrolled in both tertiary education and in upper-secondary general and vocational schooling

The declared aim of the Thai loan scheme to increase the access of the poor to upper-secondary and tertiary educationthrough the targeting of loans to needy students under extremely favorable repayment conditions-has been complemented, de facto, by other objectives. Thus while the scheme was not designed as a vehicle for extensive cost recovery, the introduction of the scheme in 1996 was accompanied by increases in tuition fees at public educational institutions, though not at all of them.

The Thai scheme is of considerable interest, as one of the few examples of a national loan scheme that is both unambiguously aimed at serving disadvantaged groups of the population and also relatively large in size and wide in student coverage, ensuring a strong national impact. The scheme is run through 